\title{
Short-term dual antiplatelet therapy after interventional left atrial appendage closure with different devices
}

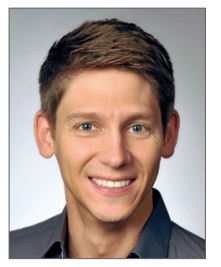

Felix K. Weise, MD; Stefano Bordignon, MD; Laura Perrotta, MD, PhD; Athanasios Konstantinou, MD; Fabrizio Bologna, MD; Takahiko Nagase, MD; Shaojie Chen, MD; K.R. Julian Chun, MD; Boris Schmidt*, MD

Cardioangiologisches Centrum Bethanien, Frankfurt am Main, Germany

This paper also includes supplementary data published online at: http://www.pcronline.com/eurointervention/133rd_issue/354

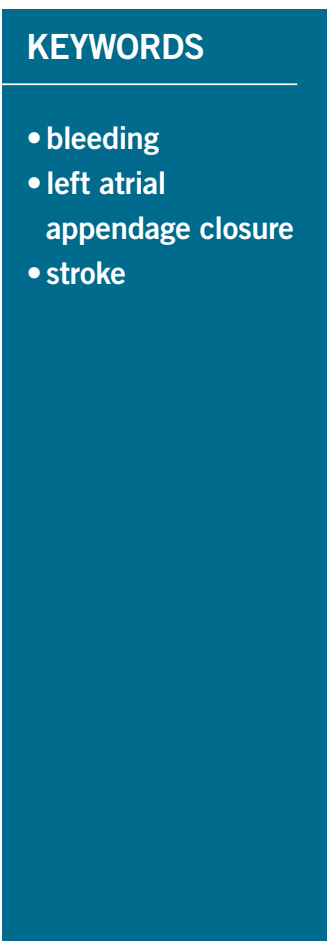

\begin{abstract}
Aims: We aimed to assess the feasibility, efficacy and safety of short-term dual antiplatelet therapy (DAPT) for six weeks after left atrial appendage closure (LAAC).

Methods and results: Data of the Cardioangiologisches Centrum Bethanien-LAAC registry were analysed. DAPT (aspirin $100 \mathrm{mg}$ plus clopidogrel $75 \mathrm{mg}$ ) was administered until transoesophageal echocardiography (TEE) evaluation six weeks after LAAC. In the absence of significant peri-device flow or device-related thrombus (DRT), the medication was decreased to single antiplatelet therapy (SAPT). Outpatient visits were timed at six-month intervals. The incidences of major bleeding (BARC $\geq 3$ ) and of thromboembolic events were investigated. A total of 298 patients ( $76 \pm 8$ years; $62 \%$ male; $\mathrm{CHA}_{2} \mathrm{DS}_{2}-\mathrm{VASc}$ $4.3 \pm 1.5$; HAS-BLED $3.5 \pm 1.0 ; 61 \%$ with history of bleeding) with successful LAAC were included. TEE revealed DRT in 7/298 (2.3\%) patients (five at six-week follow-up [FU] 45 10 days after implant, two during a median long-term FU of 731 days). Non-procedure-related bleeding events occurred in 25/298 (8.4\%) patients and non-procedure-related thromboembolic events in 11/298 (3.7\%) patients. This translated into 3.9 bleeding events/100 patient-years and 1.7 thromboembolic events/100 patient-years, respectively. Procedure-related events consisted of major bleeding in 7/298 (2.3\%) patients and stroke in 2/298 $(0.7 \%)$ patients. Age $\geq 75$ years (OR 3.2; CI: 1.2-8.0; $\mathrm{p}=0.015$ ) and renal impairment (OR 2.5; CI: 1.1-5.7; $\mathrm{p}=0.027$ ) were identified as independent predictors for major bleeding after LAAC.
\end{abstract}

Conclusions: Short-term DAPT for six weeks appears to be a viable alternative for patients after LAAC. Age $\geq 75$ years and renal impairment increase major bleeding events threefold.

\footnotetext{
*Corresponding author: Cardioangiologisches Centrum Bethanien, Agaplesion Markus Krankenhaus, Wilhelm-Epstein-Str. 4, 60431 Frankfurt am Main, Germany.E-mail: b.schmidt@ccb.de
} 


$\begin{array}{ll}\text { Abbreviations } \\ \text { AF } & \text { atrial fibrillation } \\ \text { BARC } & \text { Bleeding Academic Research Consortium } \\ \text { CCB } & \text { Cardioangiologisches Centrum Bethanien } \\ \text { DAPT } & \text { dual antiplatelet therapy } \\ \text { DRT } & \text { device-related thrombus } \\ \text { FU } & \text { follow-up } \\ \text { GIB } & \text { gastrointestinal bleeding } \\ \text { LAA } & \text { left atrial appendage } \\ \text { LAAC } & \text { left atrial appendage closure } \\ \text { NOAC } & \text { new oral anticoagulants } \\ \text { OAC } & \text { oral anticoagulation } \\ \text { SAPT } & \text { single antiplatelet therapy } \\ \text { SE } & \text { systemic embolism } \\ \text { TEE } & \text { transoesophageal echocardiography } \\ \text { TIA } & \text { transient ischaemic attack } \\ \text { VKA } & \text { vitamin K antagonists }\end{array}$

\section{Introduction}

Interventional left atrial appendage closure (LAAC) is an established therapeutic option for atrial fibrillation (AF) patients at risk for thromboembolic complications and a contraindication to long-term oral anticoagulation $(\mathrm{OAC})^{1,2}$. After successful device placement, antithrombotic therapy has to be applied transiently in order to avoid device-related thrombus (DRT) formation and subsequent embolic events. Uncertainty exists on the optimal antithrombotic regimen as well as the optimal treatment duration. In large randomised clinical trials using the WATCHMAN ${ }^{\circledR}$ device (Boston Scientific, Marlborough, MA, USA), OAC plus aspirin for six weeks followed by six months of dual antiplatelet therapy (DAPT) and lifelong aspirin therapy has been proposed ${ }^{3,4}$. For the same device, six months of DAPT followed by lifelong aspirin has been proven to be efficacious in patients contraindicated to $\mathrm{OAC}^{5}$. Scarce data from controlled studies are available for alternative devices (AMPLATZER ${ }^{\mathrm{TM}}$ Cardiac Plug [ACP], Amulet ${ }^{\mathrm{TM}}$ [both St. Jude Medical, St. Paul, MN, USA]), but it is expert consensus to establish a six-month dual antiplatelet therapy ${ }^{6}$.

All regimens bear the potential risk for bleeding complications, particularly for patients with increased HAS-BLED scores ${ }^{7}$. Since patient characteristics have changed considerably with a shift towards more frailty and a very high bleeding risk, a foreshortened treatment period would be desirable.

In this single-centre observational study we investigated the feasibility of a short-term (six-week) DAPT course followed by lifelong aspirin therapy in an all-comers cohort receiving different LAAC devices. The incidence of DRT as well as the incidence of bleeding and thromboembolic events was assessed.

\section{Methods}

Data on all LAAC implant procedures at the Cardioangiologisches Centrum Bethanien (CCB) were prospectively collected in the CCB-LAAC registry. From 2010, all patients were treated according to the protocol using DAPT for six weeks after LAAC.
The local ethics committee approved the study protocol. Patients gave written informed consent prior to the procedure.

\section{PATIENTS}

Two interventional cardiologists evaluated the indication for the LAAC procedure in line with the current expert consensus document ${ }^{6}$. Data on age, gender, AF type and duration as well as concomitant medical diseases were assessed. Contemporary risk scores for thromboembolism $\left(\mathrm{CHA}_{2} \mathrm{DS}_{2}\right.$-VASc) as well as bleeding (HAS-BLED) were calculated ${ }^{7-9}$.

\section{PROCEDURE}

All procedures were performed in deep sedation, and unfractionated heparin was given at a dose of 70-100 IU/kg body weight. A single transseptal puncture with an 8 Fr sheath (SL1'TM; St. Jude Medical) using the modified Brockenbrough technique was performed under transoesophageal echocardiography (TEE) (Vivid ${ }^{\mathrm{TM}}$ 7; GE Healthcare, Horten, Norway) guidance. Left atrial appendage (LAA) angiographies were obtained in two different angulations. The diameters of the putative landing zone were assessed and compared to echocardiographic measurements.

\section{WATCHMAN AND WATCHMAN FLX'M IMPLANTATION}

The delivery sheath (14 Fr) was advanced to the LAA. Device release was realised by unsheathing, i.e., slowly retracting the sheath across the compressed device remaining in its position.

\section{ACPIAMULET IMPLANTATION}

After insertion of the delivery sheath (TorqVue ${ }^{\mathrm{TM}}$ 12-14 Fr; St. Jude Medical), the device was advanced to the left atrium and partially released for cannulation of the LAA landing zone. Sequential device release was performed by unsheathing and actively pushing the lobe. Thereafter, the device disc was positioned outside the LAA ostium.

\section{COHEREX WAVECRESTTM (COHEREX MEDICAL, SALT LAKE CITY, UT, USA) IMPLANTATION}

A pre-shaped delivery sheath $\left(17 \mathrm{Fr} ; 60-90^{\circ}\right)$ was directed to the LAA neck. The pre-loaded device attached to a delivery catheter was advanced, and device release was accomplished by an unsheathing manoeuvre followed by an active deployment of the device anchors.

\section{ECHOCARDIOGRAPHIC EVALUATION}

Device compression and residual flow were assessed. Pericardial effusion was ruled out.

\section{ANTITHROMBOTIC REGIMEN}

Immediately after the implantation procedure, a loading dose of $250 \mathrm{mg}$ aspirin intravenously in addition to $300 \mathrm{mg}$ clopidogrel per os was administered. Thereafter, aspirin $100 \mathrm{mg}$ in combination with clopidogrel $75 \mathrm{mg}$ once daily was prescribed for six weeks. Oral anticoagulants were stopped. 


\section{FOLLOW-UP}

A chest X-ray was obtained to exclude device embolisation. Six weeks after LAAC, a TEE was performed to assess DRT and peridevice flow. In case of patent LAAC without DRT, clopidogrel was stopped. Single antiplatelet therapy (SAPT) using aspirin $100 \mathrm{mg} / \mathrm{d}$ was continued indefinitely.

In case of peri-device flow $>5 \mathrm{~mm}$, DAPT was continued for another six weeks. In case of DRT, patients were treated with lowmolecular-weight heparin $(1 \mathrm{mg} / \mathrm{kg}$ body weight enoxaparin subcutaneously twice daily) for four weeks in addition to DAPT.

Patients were scheduled for outpatient visits at six-month intervals to assess any adverse events (stroke, bleeding, hospitalisation), current medication, 12-lead electrocardiogram and transthoracic echo. For patients not attending, telephonic followups were performed instead. In case of thromboembolic complications, a meticulous medical chart review was performed to determine the type of event, current medication and outcome. Two physicians independently adjudicated the events.

Bleeding events were categorised according to the Bleeding Academic Research Consortium (BARC) classification ${ }^{10}$.

\section{ENDPOINTS}

The primary safety endpoint was the occurrence of major bleeding defined as BARC $>2$. The primary efficacy endpoint was the incidence of any stroke or systemic embolism. The secondary efficacy endpoint was the incidence of DRT.

According to the aetiology, events were classified into i) procedure-related events (bleeding due to vascular access and pericardial effusion; stroke/systemic embolism [SE] or death $\leq 7$ days within implant), ii) non-procedure-related events occurring in the DAPT phase, and iii) non-procedure-related events after stopping DAPT until last follow-up (FU).

\section{STATISTICAL ANALYSIS}

Mean \pm standard deviation was used to describe continuous variables with normal distribution. Median and interquartile range were used when appropriate. The Student's t-test was performed to calculate differences between groups of variables with normal distribution. The chi-squared test or the Fisher's exact test was used to perform between-group comparisons. For time-to-event data, Kaplan-Meier curves and log-rank test were computed using custom software, SPSS for Windows, Version 20.0 (IBM Corp., Armonk, NY, USA).

Univariate and multivariate analyses were computed to identify predictors of major bleeding. Renal impairment was defined as serum-creatinine of $\geq 1.5 \mathrm{mg} / \mathrm{dl}^{11}$.

\section{Results \\ PATIENTS}

Between July 2010 and December 2015 a total of 298 patients successfully received an LAAC. The demographic data are given in Table 1. Patients had a mean age of $76 \pm 8$ years and $62 \%$ were male. In $61 \%$ of patients prior bleeding had occurred, and the risk
Table 1. Patient demographics.

\begin{tabular}{|l|c|r|}
\hline \multicolumn{1}{|c|}{ Characteristic } & \multicolumn{2}{c|}{ Summary statistics } \\
\hline Age at time of implantation (years) & $76 \pm 8$ & \\
\hline Male gender & $61.7 \%$ & $(184 / 298)$ \\
\hline HAS-BLED score & $3.5 \pm 1.0$ & \\
\hline CHADS $_{2}$ score & $2.5 \pm 1.2$ & \\
\hline CHA $_{2}$ DS $_{2}$-VASc score & $4.3 \pm 1.5$ & \\
\hline Congestive heart failure & $37.2 \%$ & $(111 / 298)$ \\
\hline History of hypertension & $93.3 \%$ & $(287 / 298)$ \\
\hline Age $\geq 65$ years & $89.9 \%$ & $(268 / 298)$ \\
\hline Age $\geq 75$ years & $58.7 \%$ & $(175 / 298)$ \\
\hline Diabetes type 2 & $30.5 \%$ & $(91 / 298)$ \\
\hline $\begin{array}{l}\text { History of ischaemic stroke, TIA or } \\
\text { systemic embolism }\end{array}$ & $17.4 \%$ & $(52 / 298)$ \\
\hline Vascular disease & $15.1 \%$ & $(45 / 298)$ \\
\hline Coronary artery disease & $43.6 \%$ & $(130 / 298)$ \\
\hline $\begin{array}{l}\text { Abnormal renal function } \\
\text { (creatinine } \geq 1.5 \text { mg/dl) }\end{array}$ & $17.8 \%$ & $(53 / 298)$ \\
\hline Abnormal liver function & $7.7 \%$ & $(23 / 298)$ \\
\hline History of bleeding & $60.7 \%$ & $(181 / 298)$ \\
\hline History of intracranial bleeding & $9.4 \%$ & $(28 / 298)$ \\
\hline Mean 5 (17) & \\
\hline
\end{tabular}

Mean \pm standard deviation. TIA: transient ischaemic attack

both for stroke as well as for bleeding was high as expressed by the calculated risk scores: $\mathrm{CHA}_{2} \mathrm{DS}_{2}$-VASc $4.3 \pm 1.5$; HAS-BLED $3.5 \pm 1.0$. During the course of the study, five different device types were implanted. The distribution was as follows: WATCHMAN and WATCHMAN FLX in 140/298 (47\%) patients; AMPLATZER Cardiac Plug and Amulet in 126/298 (42\%) patients; WaveCrest in $32 / 298$ (11\%) patients.

\section{FOLLOW-UP}

The first FU visit was attended by 267/298 (89.6\%) patients $45 \pm 10$ days after the implant. Long-term FU was completed by 288/298 (96.6\%) patients. The mean FU was $820 \pm 547$ days after LAAC (644.7 patient-years; median 731 days) (Table 2).

\section{PROCEDURE-RELATED EVENTS}

In all patients LAAC was successfully performed and patients were discharged on DAPT. Residual peri-device flow $\leq 5 \mathrm{~mm}$ was detected in $17(5.7 \%)$ patients, whereas significant peri-device flow $>5 \mathrm{~mm}$ was not seen.

Acute $(n=3)$ or delayed $(n=7)$ pericardial tamponade requiring subxyphoidal drainage occurred in 10/298 (3.4\%) patients. Per device distribution was as follows: WATCHMAN and WATCHMAN FLX 3/140 (2.1\%) patients, AMPLATZER Cardiac Plug and Amulet 4/126 (3.2\%) patients and WaveCrest 3/32 (9.4\%) patients (Supplementary Table 1). All patients were managed conservatively without surgery and recovered without sequelae.

Procedure-related major bleeding events occurred in $7 / 298$ $(2.3 \%)$ patients and were all related to vascular access (Figure 1). 
Table 2. Follow-up.

\begin{tabular}{|c|c|c|c|c|c|c|c|}
\hline & & Proced & days & Short-term & \pm 10 days & Long-term I & \pm 547 days \\
\hline No. of patie & & $298 / 298$ & $(100 \%)$ & $267 / 298$ & (89.6\%) & $288 / 298$ & $(96.6 \%)$ \\
\hline Follow-up > & & n.a. & & n.a. & & $258 / 298$ & $(86.6 \%)$ \\
\hline Death & & $1 / 298$ & $(0.3 \%)$ & $5 / 298$ & $(1.7 \%)$ & $50 / 298$ & (16.8\%) \\
\hline CV caus & & 0 & $(0 \%)$ & $1 / 298$ & (0.3\%) & $12 / 298$ & $(4.0 \%)$ \\
\hline Non-CV & use & 0 & (0\%) & $2 / 298$ & $(0.7 \%)$ & $27 / 298$ & (9.1\%) \\
\hline Unknov & ause & 0 & $(0 \%)$ & $1 / 298$ & $(0.3 \%)$ & $11 / 298$ & $(3.7 \%)$ \\
\hline Lost to follo & & 0 & $(0 \%)$ & $31 / 298$ & $(10.4 \%)$ & $10 / 298$ & $(3.4 \%)$ \\
\hline Medication & DAPT & $298 / 298$ & $(100 \%)$ & $244 / 298$ & (81.9\%) & $14 / 298$ & $(4.7 \%)$ \\
\hline & SAPT & 0 & (0\%) & $14 / 298$ & $(4.7 \%)$ & $222 / 298$ & $(74.5 \%)$ \\
\hline & VKA & 0 & (0\%) & $8 / 298$ & (2.7\%) & $5 / 298$ & (1.7\%) \\
\hline & NOAC & 0 & $(0 \%)$ & $0 / 298$ & $(0 \%)$ & $18 / 298$ & $(6.0 \%)$ \\
\hline & None & 0 & $(0 \%)$ & $1 / 298$ & $(0.3 \%)$ & $29 / 298$ & $(9.7 \%)$ \\
\hline TEE & No. of TEE & $298 / 298$ & $(100 \%)$ & $256 / 298$ & (85.9\%) & $101 / 298$ & (33.9\%) \\
\hline & Residual flow & $17 / 298$ & $(5.7 \%)$ & $33 / 256$ & (12.9\%) & 24/101 & (23.8\%) \\
\hline & Significant flow & 0 & $(0 \%)$ & $1 / 256$ & $(0.4 \%)$ & $1 / 101$ & $(1.0 \%)$ \\
\hline & DRT & 0 & $(0 \%)$ & $5 / 256$ & $(2.0 \%)$ & 2/101 & $(2.0 \%)$ \\
\hline
\end{tabular}

CV: cardiovascular; DAPT: dual antiplatelet therapy; DRT: device-related thrombus; FU: follow-up; No.: number; NOAC: new oral anticoagulants; SAPT: single antiplatelet therapy; TEE: transoesophageal echocardiography; VKA: vitamin $\mathrm{K}$ antagonists

Two of $298(0.7 \%)$ patients experienced an embolic stroke one day after the implant (Figure 2).

At day 6 following the implant of a WATCHMAN device one patient died at home after an uneventful hospital course. The cause of death could not be elucidated.

\section{NON-PROCEDURE-RELATED MAJOR BLEEDING EVENTS}

Non-procedure-related major bleeding events occurred in 13/298 (4.4\%) patients taking DAPT $11 \pm 16$ days after LAAC. This included gastrointestinal bleeding (GIB, $n=9)$, soft tissue bleeding $(n=3)$ and urogenital bleeding $(n=1)$.

After cessation of DAPT, 12/298 (4.0\%) patients experienced bleeding events including GIB $(n=8)$, soft tissue bleeding $(n=1)$ and intracranial bleeding $(n=3)$. While nine of these patients were on SAPT, one of the GIB was fatal and occurred in a patient without any antithrombotic medication. Two patients resumed DAPT due to medical intervention and individual decision, respectively. The chronology is illustrated in Figure 3.

Indeed, 21/25 (84.0\%) patients with non-procedure-related major bleeding events had a history of bleeding. In 17/21 (81.0\%) patients with bleeding history, the same type of bleeding occurred. Of these, $14 / 17$ (82.4\%) patients with GIB had a prior history of GIB.

The annual major bleeding rate was $3.9 \%$. Given the expected bleeding rate of $8.7 \%$, this reflects a reduction of $55.2 \%$.

\section{NON-PROCEDURE-RELATED THROMBOEMBOLIC EVENTS}

In total, 11/298 (3.7\%) patients experienced a non-procedurerelated thromboembolic event (stroke, $n=10 ; \mathrm{SE}, \mathrm{n}=1$ ) during

\begin{tabular}{|c|c|c|}
\hline & \multicolumn{2}{|c|}{$\begin{array}{l}\text { All major bleeding events } \\
n=32 / 298(10.7 \%)\end{array}$} \\
\hline \multirow[t]{2}{*}{$\begin{array}{c}\text { Procedure-related } \\
\mathrm{n}=7 / 298(2.3 \%)\end{array}$} & \multicolumn{2}{|c|}{$\begin{array}{c}\text { Non-procedure-related } \\
n=25 / 298(8.4 \%)\end{array}$} \\
\hline & $\begin{array}{l}\text { DAPT post implant } \\
\mathrm{n}=13 / 298(4.4 \%)\end{array}$ & $\begin{array}{l}\text { Destination therapy } \\
n=12 / 298(4.0 \%)\end{array}$ \\
\hline $\begin{array}{l}\text { - Vascular access, } n=7 \\
\quad(\text { DAPT, } n=6 ; \text { SAPT, } n=1 \text { ) }\end{array}$ & $\begin{array}{l}\text { - GIB, } n=9 \\
\text { - Soft tissue, } n=3 \\
\text { - Urogenital, } n=1\end{array}$ & $\begin{array}{l}\text { - GIB, } n=7\left(6 \times S A P T, 1 \times D_{A P T}^{*}\right) \\
\text { - Fatal GIB, } n=1 \text { (None) } \\
\text { - Soft tissue, } n=1 \text { (SAPT) } \\
\text { - ICB, } n=3\left(2 \times \text { SAPT, } 1 \times \text { DAPT }^{*}\right)\end{array}$ \\
\hline
\end{tabular}

Figure 1. Summary of major bleeding events. *Transient DAPT due to medical intervention and individual decision, respectively. DAPT: dual antiplatelet therapy; GIB: gastrointestinal bleeding; ICB: intracranial bleeding; SAPT: single antiplatelet therapy 


\begin{tabular}{|c|c|c|}
\hline \multicolumn{3}{|c|}{$\begin{array}{l}\text { All thromboembolic events } \\
n=13 / 298(4.4 \%)\end{array}$} \\
\hline \multirow[t]{2}{*}{$\begin{array}{c}\text { Procedure-related } \\
n=2 / 298(0.7 \%)\end{array}$} & \multicolumn{2}{|c|}{$\begin{array}{c}\text { Non-procedure-related } \\
n=11 / 298(3.7 \%)\end{array}$} \\
\hline & $\begin{array}{l}\text { DAPT post implant } \\
\mathrm{n}=1 / 298(0.3 \%)\end{array}$ & $\begin{array}{c}\text { Destination therapy } \\
n=10 / 298(3.4 \%)\end{array}$ \\
\hline $\begin{array}{l}\text { - Stroke, } \mathrm{n}=2 \\
\quad \text { ( } 1 \text { day post implant) }\end{array}$ & - Stroke, n=1 & $\begin{array}{l}\text { - Stroke, } \mathrm{n}=8 \\
\quad \text { (SAPT, } \mathrm{n}=5 ; \text { None, } \mathrm{n}=3 \text { ) } \\
\text { - Fatal stroke, } \mathrm{n}=1(\mathrm{DAPT} \text { ) } \\
\text { - } \mathrm{SE}, \mathrm{n}=1 \text { (SAPT) }\end{array}$ \\
\hline
\end{tabular}

Figure 2. Summary of thromboembolic events. *Transient DAPT due to medical intervention. DAPT: dual antiplatelet therapy; SAPT: single antiplatelet therapy; SE: systemic embolism

the course of the study (Figure 4). Given the total FU time of 644.7 patient-years, this resulted in an annual stroke/SE rate of $1.7 \%$. Compared to the expected stroke/SE rate of $7.8 \%$, this represented a risk reduction of $78.2 \%$.

During the first six weeks after LAAC, two patients experienced embolic stroke: one patient was on DAPT and one stroke occurred
31 days post implant under SAPT in a patient with shortened time of DAPT (21 days) due to recurrence of GIB. After the postinterventional DAPT period, nine patients experienced a stroke/ SE under SAPT $(n=5)$ or no therapy $(n=3)$ or DAPT $(n=1)$. One stroke was fatal and occurred despite DAPT due to previous medical intervention (peripheral artery disease).

\begin{tabular}{|c|c|c|c|c|c|c|c|c|c|c|c|c|c|c|c|c|c|c|c|c|c|c|c|c|c|}
\hline Therapy & DAP & T pos & t impl & & & & & & & & & & & SAPT & SAPT & None & SAPT & DAPT & SAPT & SAPT & SAPT & SAPT & DAPT & SAPT & SAPT \\
\hline Bleeding, number & 1 & 2 & 3 & 4 & 5 & 6 & 7 & 8 & 9 & 10 & 11 & 12 & 13 & 14 & 15 & 16 & 17 & 18 & 19 & 20 & 21 & 22 & 23 & 24 & 25 \\
\hline Days post implant & 0 & 1 & 1 & 1 & 2 & 3 & 4 & 5 & 5 & 15 & 24 & 35 & 50 & 35 & 42 & 84 & 129 & 141 & 153 & 164 & 226 & 250 & 409 & 492 & 624 \\
\hline Type & GIB & GIB & ST & GIB & GIB & UB & ST & GIB & GIB & GIB & GIB & GIB & ST & ICB & GIB & GIB & GIB & ICB & GIB & GIB & ST & ICB & GIB & GIB & GIB \\
\hline Severity, BARC & 3a & 3a & 3a & 3a & $3 b$ & $3 a$ & $3 b$ & 3a & $3 a$ & $3 a$ & $3 a$ & $3 a$ & $3 a$ & $3 c$ & $3 a$ & $5 b$ & $3 a$ & $3 c$ & $3 a$ & $3 a$ & $3 a$ & $3 c$ & $3 b$ & $3 a$ & $3 a$ \\
\hline 山Ш山 | & $\perp$ & 1 & & & & 1 & & & & & & & $\perp$ & 1 & & & & & & & & & & & \\
\hline $\begin{array}{l}\mathrm{P} \quad 5 \mathrm{~d} \\
\text { |DAPT I SA }\end{array}$ & & $\begin{array}{l}45 \pm 1 \\
\text { INoI }\end{array}$ & & & & & & & & & & 200 & & & & & 400 & & & & & $600 d$ & & & \\
\hline
\end{tabular}

Figure 3. Timing of non-procedure-related major bleeding events. BARC: Bleeding Academic Research Consortium; d: days post procedure; DAPT: dual antiplatelet therapy; GIB: gastrointestinal bleeding; ICB: intracranial bleeding; P: procedure; SAPT: single antiplatelet therapy; ST: soft tissue; UB: urogenital bleeding

\begin{tabular}{|c|c|c|c|c|c|c|c|c|c|c|c|}
\hline Therapy & DAPT & SAPT* & SAPT & SAPT & None & SAPT & DAPT $^{+}$ & SAPT & SAPT & None & None \\
\hline Stroke/SE, number & 1 & 2 & 3 & 4 & 5 & 6 & 7 & 8 & 9 & 10 & 11 \\
\hline Days post implant & 28 & 31 & 80 & 217 & 291 & 349 & 428 & 471 & 492 & 839 & 934 \\
\hline Type of event & Stroke & Stroke & SE & Stroke & Stroke & Stroke & Stroke & Stroke & Stroke & Stroke & Stroke \\
\hline Days after DAPT & n.a. & 10 & 31 & 178 & 250 & 302 & n.a. & 424 & 448 & 798 & 891 \\
\hline $\mathrm{mRS}$ & 1 & 4 & n.a. & 3 & 1 & 1 & fatal & 0 & 0 & 2 & 1 \\
\hline DRT & no & no & no & no & no & no & n.a. & no & no & no & no \\
\hline $\begin{array}{l}\text { P } \\
\text { IDAPT ISAPT INone }\end{array}$ & & $300 \mathrm{~d}$ & & & & 600 & & & & 90 & \\
\hline
\end{tabular}

Figure 4. Timing of non-procedure-related thromboembolic events. *DAPT stopped 21 days after implant due to gastrointestinal bleeding. ${ }^{+}$Transient DAPT due to medical intervention. d: days post procedure; DAPT: dual antiplatelet therapy; DRT: device-related thrombus; mRS: modified Rankin Scale; n.a.: not applicable; P: procedure; SAPT: single antiplatelet therapy; SE: systemic embolism 
The first stroke after the designated time of DAPT was noted 178 days after its cessation.

In 10/11 (91\%) patients with thromboembolic events, DRT as well as significant peri-device flow were excluded.

Figure 5 shows the Kaplan-Meier plots of all major bleeding and thromboembolic events.

\section{DEVICE-RELATED THROMBUS}

At first FU $45 \pm 10$ days after LAAC, TEE was performed in $256 / 298(85.9 \%)$ patients. In 5/256 (2.0\%) patients on DAPT, DRT was detected (WATCHMAN and WATCHMAN FLX, $n=3$; AMPLATZER Cardiac Plug and Amulet, $n=2)$. Significant peridevice flow was seen in one patient (WATCHMAN).

During the course of the study, TEE was performed in 101/298 (33.9\%) patients for various clinical indications at $341 \pm 271$ days after LAAC. DRT was detected in 2/101 (2.0\%) patients on SAPT. The significant peri-device flow in the above-mentioned patient was still present.

Throughout long-term FU, therapy regimens consisted of no antithrombotic medication $(n=29 / 298 ; 9 \%)$, SAPT $(n=222 / 298$;
$75 \%)$ and DAPT ( $\mathrm{n}=14 / 298 ; 5 \%)$. Only 5/298 (2\%) and 18/298 (6\%) patients had resumed vitamin $\mathrm{K}$ antagonist (VKA) therapy and new oral anticoagulants (NOAC), respectively. The reasons for resuming long-term OAC were stroke $(n=7)$, pulmonary embolism/deep vein thrombosis $(n=5)$ and individual decision of the general practitioner $(n=7)$. In two cases the reason could not be elucidated. Transient OAC resumption $(n=2)$ was performed after left atrial ablation.

Altogether 50/298 (16.8\%) patients had died from cardiovascular $(n=12)$, non-cardiovascular $(n=27)$ and unknown $(n=11)$ causes. One patient died during the DAPT phase 31 days after implant for an unknown reason.

\section{UNIVARIATE AND MULTIVARIATE ANALYSIS}

In order to determine risk factors for bleeding, univariate and multivariate analyses were computed (Table 3 ). Age $>75$ years (OR 3.2; CI: 1.2-8.0; $\mathrm{p}=0.015$ ) and renal impairment (OR 2.5; CI: 1.1$5.7 ; \mathrm{p}=0.027$ ) were identified as independent predictors of recurrent bleeding after LAAC.
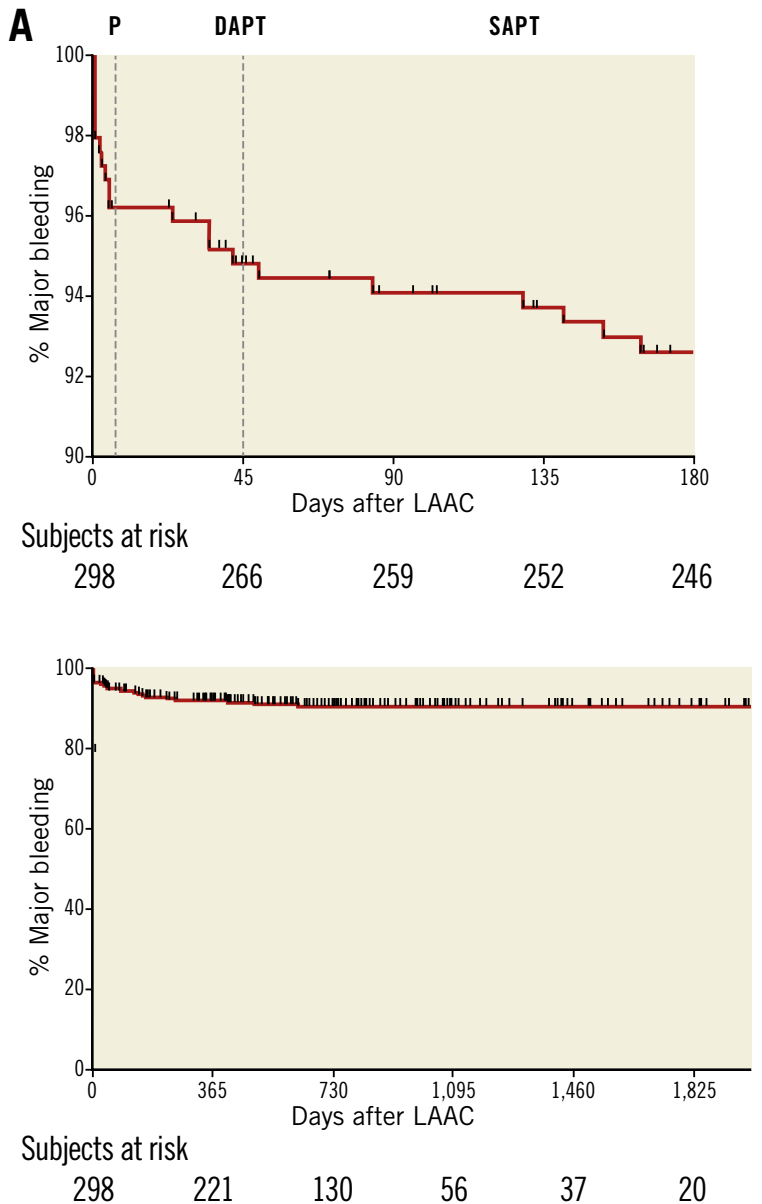
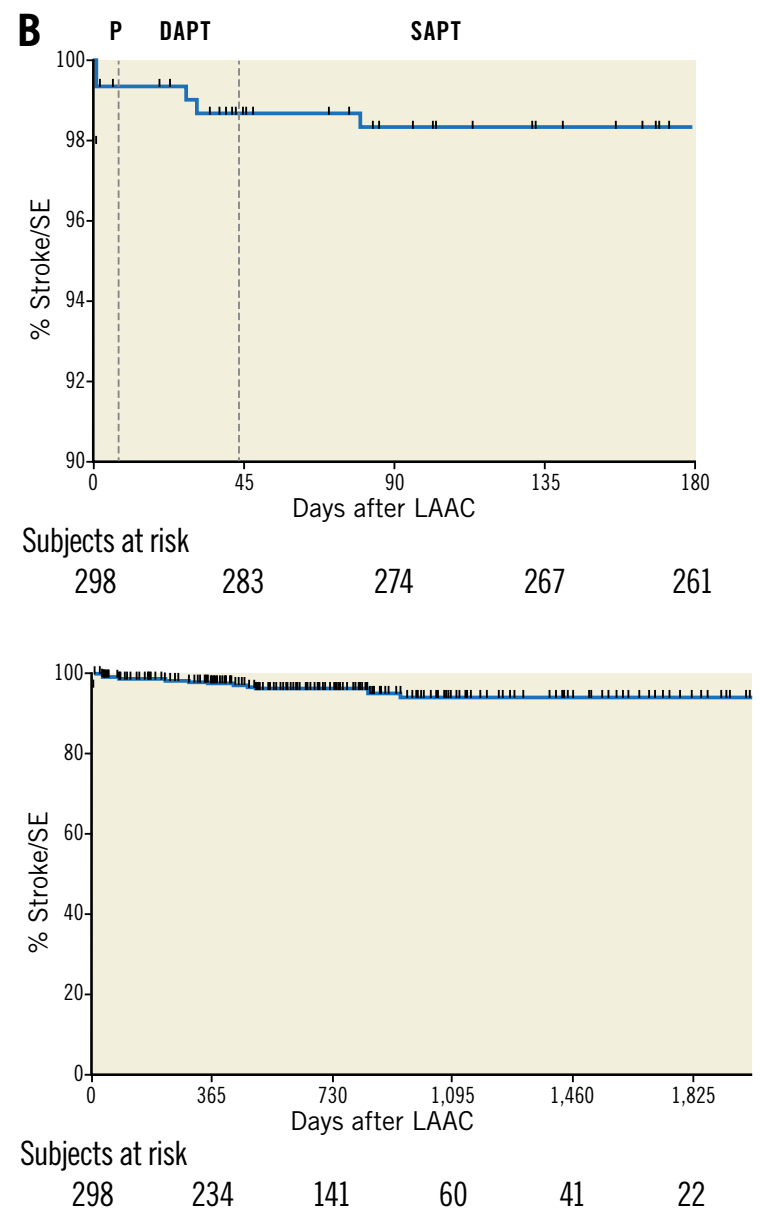

Figure 5. Kaplan-Meier plots of major bleeding and thromboembolic events. A) Major bleeding events. B) Thromboembolic events (stroke/SE). The upper graphs depict the transition from DAPT to destination therapy after TEE at six weeks (dotted lines), while the lower graphs illustrate the entire follow-up. DAPT: dual antiplatelet therapy; LAAC: left atrial appendage closure; P: procedure; SAPT: single antiplatelet therapy; SE: systemic embolism 
Table 3. Univariate and multivariate analysis for major bleeding events.

\begin{tabular}{|c|c|c|c|c|c|}
\hline & $\begin{array}{l}\text { Major bleeding } \\
\qquad(n=32)\end{array}$ & $\begin{array}{c}\text { No major bleeding } \\
(n=272)\end{array}$ & $\begin{array}{c}\text { Univariate } \\
\boldsymbol{p} \text {-value }\end{array}$ & OR (95\% Cl) & $\begin{array}{c}\text { Multivariate } \\
\boldsymbol{p} \text {-value }\end{array}$ \\
\hline Age at time of implantation (years) & $79 \pm 6$ & $75 \pm 8$ & 0.003 & & \\
\hline Male gender & $62.5 \%(20)$ & $61.7 \%(164)$ & 1.000 & & \\
\hline HAS-BLED score & $4.0 \pm 0.8$ & $3.5 \pm 1.1$ & 0.011 & $1.4(0.9-2.2)$ & 0.122 \\
\hline $\mathrm{CHA}_{2} \mathrm{DS}_{2}$-VASc score & $4.9 \pm 1.3$ & $4.2 \pm 1.5$ & 0.012 & $1.2(0.9-1.7)$ & 0.144 \\
\hline Congestive heart failure & $43.8 \%(14)$ & $36.5 \%(97)$ & 0.443 & & \\
\hline History of hypertension & $100.0 \%(32)$ & $92.5 \%(246)$ & 0.145 & & \\
\hline Age $\geq 65$ years & $96.9 \%(31)$ & $89.1 \%(237)$ & 0.223 & & \\
\hline Age $\geq 75$ years & $81.3 \%(26)$ & $56.0 \%(149)$ & 0.007 & $3.2(1.2-8.0)$ & 0.015 \\
\hline Diabetes type 2 & $43.8 \%(14)$ & $28.9 \%(77)$ & 0.104 & & \\
\hline History of ischaemic stroke, TIA or systemic embolism & $21.9 \%(7)$ & $16.9 \%(45)$ & 0.465 & & \\
\hline Vascular disease & $18.8 \%(6)$ & $14.7 \%(39)$ & 0.600 & & \\
\hline Coronary artery disease & $37.5 \%(12)$ & $44.4 \%(118)$ & 0.572 & & \\
\hline Abnormal renal function (creatinine $\geq 1.5 \mathrm{mg} / \mathrm{dl}$ ) & $34.4 \%(11)$ & $15.8 \%(42)$ & 0.014 & $2.5(1.1-5.7)$ & 0.027 \\
\hline Abnormal liver function & $12.5 \%(4)$ & $7.1 \%(19)$ & 0.289 & & \\
\hline History of bleeding & $75.0 \%(24)$ & $59.0 \%(157)$ & 0.088 & & \\
\hline
\end{tabular}

\section{Discussion}

LAAC has evolved to an established therapeutic option for stroke prophylaxis in patients with contraindications to OAC. Recently published real-life registries underscore the efficacy in stroke risk reduction as well as the procedural safety of this intervention ${ }^{12,13}$. However, uncertainty exists on the optimal postimplant antithrombotic strategy in this patient population with a high bleeding risk. An expert consensus statement provided recommendations for the two most commonly used devices (WATCHMAN and AMPLATZER Cardiac Plug) ${ }^{14}$. Depending on device type and individual bleeding risk, different antithrombotic regimens including VKA or DAPT were recommended. However, the consensus document remains relatively vague with respect to DAPT treatment duration, ranging from one to six months. The absence of a clear-cut standard is reflected by the results of the aforementioned real-life registries (EWOLUTION and AMULET) that showed a wide variety of antithrombotic regimens being used in everyday clinical practice with a clear trend towards DAPT. Alternatively, individualised strategies were applied using SAPT, VKA, NOAC or even no therapy at all without any significant differences between groups with regard to DRT or clinical events ${ }^{15}$. This has ultimately led to a change in labelling for the WATCHMAN device.

The optimal duration of DAPT, however, remains unclear. Intermediate-term DAPT for six months after LAAC proved ample efficacy in preventing DRT and thromboembolic events in the ASAP study but was also found to be associated with a considerable number of bleeding events ${ }^{5}$. Whilst others have addressed this dilemma by de-escalating DAPT to SAPT using aspirin, the present concept shortened DAPT duration to six weeks ${ }^{16}$. As expected, the incidence of bleeding was strongly correlated to the intensity of antithrombotic therapy. While $4.4 \%$ of patients using
DAPT experienced a major bleeding, fewer events were noted after DAPT cessation during extended FU.

Most importantly, early DAPT cessation did not lead to a higher incidence of thromboembolic events. In fact, the first stroke was noted 178 days after DAPT cessation. The observed annual stroke/SE rate of $1.7 \%$ is similar to previous reports such as the PREVAIL study $(2.7 \%)^{4}$.

The present data also show that DAPT was effective in preventing DRT on different occluder devices. The $1.7 \%$ DRT rate is well in line with contemporary reports in similar patient populations

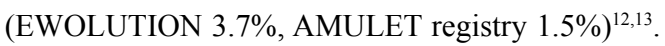

Although neither the present nor the aforementioned study with a SAPT strategy was designed to prove improved safety and efficacy compared to longer-term DAPT treatment, both may add valuable information in the setting of high-risk patients after LAAC. As an alternative to DAPT, the use of low-dose NOAC appears to be a viable management strategy after LAAC according to recently published data ${ }^{17}$.

Data from contemporary real-life registries demonstrated that a minority of patients had been treated without any antithrombotic therapy after LAAC without a higher incidence of device thrombosis. Although this may represent a tempting strategy for very high-risk patients, the patient number was too low to justify general recommendations.

Recently, it appeared that bleeding is the most prevalent adverse event after LAAC, occurring at a rate of $4.1 \%{ }^{15}$. Since European guidelines recommend interventional LAAC exclusively for patients with contraindications to long-term $\mathrm{OAC}$, i.e., patients at high risk for bleeding, medical strategies to reduce that risk are warranted ${ }^{1}$. Among this patient population, this study identified elderly people $>75$ years and patients with impaired renal function as being at a threefold risk for bleeding events using DAPT after LAAC. 
The latter is well in line with previous reports from the retrospective ACP registry, showing that patients with chronic kidney disease had a higher bleeding event rate with more severe renal impairment and even a higher mortality in those with a glomerular filtration rate of $<30 \mathrm{ml} / \mathrm{min}^{18}$. On the other hand, the analysis on the association of age with adverse outcome in the ACP registry did not identify patients $>75$ years as being at a higher risk. However, the postimplant antithrombotic strategy was not standardised and individualised concepts for the elderly might have confounded the data ${ }^{19}$.

It remains to be determined if this patient population should be treated with less aggressive strategies such as SAPT, as recently suggested for patients at high risk for intracranial haemorrhage, or even no therapy ${ }^{16}$.

Serious periprocedural complications during LAAC implantations have been substantially reduced to $2.7 \%$ during the first seven days after the implant ${ }^{12}$. In the subacute phase after LAAC, prevention of thrombus on the incompletely endothelialised device and subsequent thromboembolism is of the utmost importance. Treatment strategies include antiplatelet therapy as well as anticoagulation and a combination of these.

\section{Limitations}

Several factors need to be taken into consideration when interpreting the present results. First, the study is purely observational and lacks a control group. Future randomised studies may be needed to determine the value of short-term DAPT in comparison to other strategies. Second, the sample size of this single-centre study is rather small and included different device types. The follow-up at 45 days was attended by $89.6 \%$ of patients and $85.9 \%$ underwent TEE evaluation. Therefore, the total DRT rate may be underestimated, but the protocol compliance rate resembles that of the EWOLUTION registry study $(94 \%)^{15}$

However, the results are well in line with the latest real-life clinical registry studies where DAPT was the predominant strategy after $\mathrm{LAAC}^{12,13}$.

\section{Conclusions}

Short-term DAPT for six weeks appears to be a viable alternative for patients after LAAC. Age $>75$ years and renal impairment increase major bleeding events threefold; therefore, less aggressive antithrombotic strategies in these patient populations deserve investigation.

\section{Impact on daily practice}

Bleeding is the most prevalent adverse event after LAAC, and the incidence correlates with the intensity of the antithrombotic regimen. Short-term DAPT for six weeks has the potential to decrease bleeding events while the earlier cessation of DAPT did not lead to a higher rate of thromboembolic events. Age $>75$ years and renal impairment could be identified as independent risk factors for major bleeding. It remains to be determined if these patient populations should be treated with less aggressive strategies.

\section{Conflict of interest statement}

B. Schmidt reports receiving personal fees from Abbott and Boston Scientific outside the submitted work and is a member of the advisory board of Abbott and Boston Scientific. K.R.J. Chun reports receiving personal fees from Abbott and Boston Scientific outside the submitted work. The other authors have no conflicts of interest to declare.

\section{References}

1. Kirchhof P, Benussi S, Kotecha D, Ahlsson A, Atar D, Casadei B, Castella M, Diener HC, Heidbuchel H, Hendriks J, Hindricks G, Manolis AS, Oldgren J, Popescu BA, Schotten U, Van Putte B, Vardas P; ESC Scientific Document Group. 2016 ESC Guidelines for the management of atrial fibrillation developed in collaboration with EACTS. Eur Heart J. 2016;37: 2893-962.

2. Lewalter T, Ibrahim R, Albers B, Camm AJ. An update and current expert opinions on percutaneous left atrial appendage occlusion for stroke prevention in atrial fibrillation. Europace. 2013;15:652-6.

3. Holmes DR, Reddy VY, Turi ZG, Doshi SK, Sievert H, Buchbinder M, Mullin CM, Sick P; PROTECT AF Investigators. Percutaneous closure of the left atrial appendage versus warfarin therapy for prevention of stroke in patients with atrial fibrillation: a randomised non-inferiority trial. Lancet. 2009;374:534-42.

4. Holmes DR Jr, Kar S, Price MJ, Whisenant B, Sievert H, Doshi SK, Huber K, Reddy VY. Prospective randomized evaluation of the Watchman Left Atrial Appendage Closure device in patients with atrial fibrillation versus long-term warfarin therapy: the PREVAIL trial. J Am Coll Cardiol. 2014;64:1-12.

5. Reddy VY, Möbius-Winkler S, Miller MA, Neuzil P, Schuler G, Wiebe J, Sick P, Sievert H. Left atrial appendage closure with the Watchman device in patients with a contraindication for oral anticoagulation: the ASAP study (ASA Plavix Feasibility Study With Watchman Left Atrial Appendage Closure Technology). J Am Coll Cardiol. 2013;61:2551-6.

6. Meier B, Blaauw Y, Khattab AA, Lewalter T, Sievert H, Tondo C, Glikson M; Document Reviewers. EHRA/EAPCI expert consensus statement on catheter-based left atrial appendage occlusion. Europace. 2014;16:1397-416.

7. Pisters R, Lane DA, Nieuwlaat R, de Vos CB, Crijns HJ, Lip GY. A novel user-friendly score (HAS-BLED) to assess 1-year risk of major bleeding in patients with atrial fibrillation: the Euro Heart Survey. Chest. 2010;138:1093-100.

8. Olesen JB, Lip GY, Hansen ML, Hansen PR, Tolstrup JS, Lindhardsen J, Selmer C, Ahlehoff O, Olsen AM, Gislason GH, Torp-Pedersen C. Validation of risk stratification schemes for predicting stroke and thromboembolism in patients with atrial fibrillation: nationwide cohort study. BMJ. 2011;342:d124.

9. Friberg L, Rosenqvist M, Lip GY. Evaluation of risk stratification schemes for ischaemic stroke and bleeding in 182678 patients with atrial fibrillation: the Swedish Atrial Fibrillation cohort study. Eur Heart J. 2012;33:1500-10. 
10. Mehran R, Rao SV, Bhatt DL, Gibson CM, Caixeta A, Eikelboom J, Kaul S, Wiviott SD, Menon V, Nikolsky E, Serebruany V, Valgimigli M, Vranckx P, Taggart D, Sabik JF, Cutlip DE, Krucoff MW, Ohman EM, Steg PG, White H. Standardized bleeding definitions for cardiovascular clinical trials: a consensus report from the Bleeding Academic Research Consortium. Circulation. 2011;123:2736-47.

11. Connolly SJ, Eikelboom J, Joyner C, Diener HC, Hart R, Golitsyn S, Flaker G, Avezum A, Hohnloser SH, Diaz R, Talajic M, Zhu J, Pais P, Budaj A, Parkhomenko A, Jansky P, Commerford P, Tan RS, Sim KH, Lewis BS, Van Mieghem W, Lip GY, Kim JH, Lanas-Zanetti F, Gonzalez-Hermosillo A, Dans AL, Munawar M, O'Donnell M, Lawrence J, Lewis G, Afzal R, Yusuf S; AVERROES Steering Committee and Investigators. Apixaban in patients with atrial fibrillation. $N$ Engl J Med. 2011;364:806-17.

12. Boersma LV, Schmidt B, Betts TR, Sievert H, Tamburino C, Teiger E, Pokushalov E, Kische S, Schmitz T, Stein KM, Bergmann MW; EWOLUTION investigators. Implant success and safety of left atrial appendage closure with the WATCHMAN device: peri-procedural outcomes from the EWOLUTION registry. Eur Heart J. 2016;37:2465-74.

13. Landmesser U, Schmidt B, Nielsen-Kudsk JE, Lam SCC, Park JW, Tarantini G, Cruz-Gonzalez I, Geist V, Della Bella P, Colombo A, Zeus T, Omran H, Piorkowski C, Lund J, Tondo C, Hildick-Smith D. Left atrial appendage occlusion with the AMPLATZER Amulet device: periprocedural and early clinical/ echocardiographic data from a global prospective observational study. EuroIntervention. 2017;13:867-76.

14. Meier B, Blaauw Y, Khattab AA, Lewalter T, Sievert H, Tondo C, Glikson M. EHRA/EAPCI expert consensus statement on catheter-based left atrial appendage occlusion. EuroIntervention. 2015;10:1109-25.

15. Bergmann MW, Betts TR, Sievert H, Schmidt B, Pokushalov E, Kische S, Schmitz T, Meincke F, Stein KM, Boersma LVA, Ince H. Safety and efficacy of early anticoagulation drug regimens after WATCHMAN left atrial appendage closure: three-month data from the EWOLUTION prospective, multicentre, monitored international WATCHMAN LAA closure registry. EuroIntervention. 2017;13:877-84.

16. Korsholm K, Nielsen KM, Jensen JM, Jensen HK, Andersen G, Nielsen-Kudsk JE. Transcatheter left atrial appendage occlusion in patients with atrial fibrillation and a high bleeding risk using aspirin alone for post-implant antithrombotic therapy. EuroIntervention. 2017;12:2075-82.

17. Bergmann MW, Ince H, Kische S, Schmitz T, Meincke F, Schmidt B, Foley D, Betts TR, Grygier M, Protopopov AV, Stein KM, Boersma LVA. Real-world safety and efficacy of WATCHMAN LAA closure at one year in patients on dual antiplatelet therapy: results of the DAPT subgroup from the EWOLUTION all-comers study. EuroIntervention. 2018 Jan 9. [Epub ahead of print].

18. Kefer J, Tzikas A, Freixa X, Shakir S, Gafoor S, NielsenKudsk JE, Berti S, Santoro G, Aminian A, Landmesser U, Nietlispach F, Ibrahim R, Danna PL, Benit E, Budts W, Stammen F, De Potter T, Tichelbäcker T, Gloekler S, Kanagaratnam P, Costa M, Cruz-Gonzalez I, Sievert H, Schillinger W, Park JW, Meier B, Omran H. Impact of chronic kidney disease on left atrial appendage occlusion for stroke prevention in patients with atrial fibrillation. Int J Cardiol. 2016;207:335-40.

19. Freixa X, Gafoor S, Regueiro A, Cruz-Gonzalez I, Shakir S, Omran H, Berti S, Santoro G, Kefer J, Landmesser U, NielsenKudsk JE, Sievert H, Kanagaratnam P, Nietlispach F, Gloekler S, Aminian A, Danna P, Rezzaghi M, Stock F, Stolcova M, Costa M, Ibrahim R, Schillinger W, Park JW, Meier B, Tzikas A. Comparison of Efficacy and Safety of Left Atrial Appendage Occlusion in Patients Aged $<75$ to $\geq 75$ Years. Am J Cardiol. 2016;117:84-90.

\section{Supplementary data}

Supplementary Table 1. Per device distribution: pericardial effusion and TEE results.

\author{
The supplementary data are published online at: \\ http://www.pcronline.com/ \\ eurointervention/133rd_issue/354
}




\section{Supplementary data}

Supplementary Table 1. Per device distribution: pericardial effusion and TEE results.

\begin{tabular}{|c|c|c|c|c|}
\hline & $\begin{array}{l}\text { WATCHMAN/WATCHMAN } \\
\text { FLX } \\
\text { n=140 }\end{array}$ & $\begin{array}{l}\text { ACP/Amulet } \\
n=126\end{array}$ & $\begin{array}{l}\text { WaveCrest } \\
\mathrm{n}=32\end{array}$ & $\begin{array}{l}\text { Total } \\
\mathrm{n}=298\end{array}$ \\
\hline \multicolumn{5}{|l|}{ PROCEDURE } \\
\hline $\mathbf{P E}$ & $3 / 140(2.1 \%)$ & $4 / 126(3.2 \%)$ & $3 / 32(9.4 \%)$ & $10 / 298(3.4 \%)$ \\
\hline - acute (intraprocedural) & $1 / 140(0.7 \%)$ & $2 / 126(1.6 \%)$ & $0(0 \%)$ & 3/298 (1.0\%) \\
\hline - delayed & 2/140 (1.4\%) d1, d1 & 2/126 (1.6\%) d1, d1 & $3 / 32(9.4 \%) \quad \mathrm{d} 1, \mathrm{~d} 1, \mathrm{~d} 18$ & 7/298 (2.3\%) \\
\hline No. of TEE & $140 / 140(100 \%)$ & $126 / 126(100 \%)$ & $32 / 32(100 \%)$ & 298/298 (100\%) \\
\hline Peri-device flow & 11/140 (7.9\%) & 5/126 (4.0\%) & 1/32 (3.1\%) & 17/298 (5.7\%) \\
\hline - residual flow $\leq 5 \mathrm{~mm}$ & $11 / 140(7.9 \%)$ & $5 / 126(4.0 \%)$ & $1 / 32(3.1 \%)$ & $17 / 298(5.7 \%)$ \\
\hline - significant flow $>5 \mathrm{~mm}$ & $0(0 \%)$ & $0(0 \%)$ & $0 \quad(0 \%)$ & $0(0 \%)$ \\
\hline DRT & $0(0 \%)$ & $0(0 \%)$ & $0 \quad(0 \%)$ & $0(0 \%)$ \\
\hline \multicolumn{5}{|l|}{ SHORT-TERM FU } \\
\hline No. of TEE & $115 / 140(82.1 \%)$ & $111 / 126(88.1 \%)$ & $30 / 32(93.8 \%)$ & $256 / 298(85.9 \%)$ \\
\hline Peri-device flow & 19/115 (16.5\%) & 10/111 (9.0\%) & $1 / 30(3.3 \%)$ & 34/256 (13.3\%) \\
\hline - residual flow $\leq 5 \mathrm{~mm}$ & 18/115 (15.7\%) & 10/111 (9.0\%) & $1 / 30(3.3 \%)$ & $33 / 256(12.9 \%)$ \\
\hline - significant flow $>5 \mathrm{~mm}$ & $1 / 115(0.9 \%)^{*}$ & $0(0 \%)$ & $0 \quad(0 \%)$ & $1 / 256(0.4 \%)$ \\
\hline DRT & $3 / 115(2.6 \%)$ & 2/111 (1.8) & $0 \quad(0 \%)$ & $5 / 256(2.0 \%)$ \\
\hline \multicolumn{5}{|l|}{ LONG-TERM FU } \\
\hline No. of TEE & $51 / 140$ (36.4\%) & $36 / 126$ (28.6\%) & $14 / 32(43.8 \%)$ & 101/298 (33.9\%) \\
\hline Peri-device flow & 12/51 (23.5\%) & 9/36 (25.0\%) & 4/14 (28.6\%) & 25/101 (24.8\%) \\
\hline - residual flow $\leq 5 \mathrm{~mm}$ & 11/51 (21.6\%) & 9/36 (25.0\%) & 4/14 (28.6\%) & 24/101 (23.8\%) \\
\hline - significant flow $>5 \mathrm{~mm}$ & $1 / 51$ (2.0\%)* & $0(0 \%)$ & $0 \quad(0 \%)$ & 1/101 (1.0\%) \\
\hline DRT & $1 / 51(2.0 \%)$ & 1/36 (2.8\%) & $0 \quad(0 \%)$ & 2/101 (2.0\%) \\
\hline
\end{tabular}

*same patient.

d: days after procedure; DRT: device-related thrombus; FU: follow-up; No.: number; PE: pericardial effusion; TEE: transoesophageal echocardiography 